\title{
Praying for the Liberation of the Holy Sepulchre: Franciscan Liturgy in Fifteenth Century Jerusalem
}

\begin{abstract}
The fall of Jerusalem to Saladin in 1187 and the loss of the Frankish Levant in 1291 triggered new calls for crusade and the flourishing of the literature dedicated to "the recovery of the Holy Land" (pro recuperatione Terre Sancte). The exhortation to war and the urgency of Jerusalem's deliverance were also expressed through liturgy. This article examines two liturgical texts, a "Votive mass for the recovery of the Holy Land" (Missa devota ad recuperandam Terram Sanctam) and an "Introit to the Holy Sepulchre of the Lord" (Ad Sanctum Sepulcrum Domini introitus), transmitted in manuscripts from the Franciscan library in Jerusalem, the Biblioteca Generale della Custodia di Terra Santa. This article explores the two liturgical texts in the historical context of fifteenthcentury Jerusalem, when the Franciscan friars where the only Latin clergy allowed to serve at the Holy Places. Historical accounts produced in this milieu evince the friars' efforts to memorialize the deeds of the crusader kings, celebrated as liberators of the Holy Land. The liturgical texts analysed here complement this militant memorialization.
\end{abstract}

\section{Introduction}

In 1470, almost three centuries after Saladin reconquered Jerusalem in 1187, two pilgrims arriving from Bruges, Anselmo and Giovanni Adorno, met at the Church of the Holy Sepulchre a hundred-year-old Franciscan friar, who still believed that he would see the return of Jerusalem to "Christian hands" before his death. ${ }^{1}$ Although the friar's expectations were not met by historical events, the Franciscans who settled in Jerusalem in the first half of the fourteenth century as exclusive representatives of the Roman Church continued to advocate and pray for the recovery of the Holy Land.

\footnotetext{
* Part of the research for this article was done during my doctoral studies at the University of Amsterdam, where I was a member of the research programme "Cultural Memory and Identity in the Late Middle Ages: the Franciscans of Mount Sion in Jerusalem and the Representation of the Holy Land (1333-1516)", partly financed by the Netherlands Organization for Scientific Research (NWO). I would like to thank Professor Cecilia Gaposchkin for her helpful comments on an earlier version of this article, and father Lionel Goh OFM, the director of the Biblioteca Generale della Custodia di Terra Santa, for allowing me to explore ad libitum the rich collections of this library.

1 "Sunt duo ex illis fratribus continue in ea [the Church of the Holy Sepulchre] residentes, quorum unus senex centum annorum sine baculo ambulat et cotidie celebrat. Nunquam ab eo loco exit et est pater mirabilis vite et sanctitatis qui semper affirmat se visurum ante mortem suam templum et civitatem sanctam in manu christianorum". Heers and de Groer (eds. and French trans.) 1978, 262-264 ; Morris 2005, 298.
} 
Franciscans first settled in Jerusalem in the thirteenth century. Their presence in the city did not last long, however, leaving when Jerusalem was lost by crusaders for the last time in $1244 .^{2}$ They returned to the Holy Land in the 1330s, with a papal mandate, and have remained there as Latin guardians of the Holy Places ever since. ${ }^{3}$

This article explores the role of liturgy in building a Latin and Franciscan narrative on the history of the Holy City, with a particular focus on the friars' liturgical memorialization of the crusader inheritance and their supplication for the recovery of the Holy Land. It focuses on the Franciscan "liturgy of war", namely on liturgical texts that contained explicit references to waging war for the recovery of the Holy Land and supplications for the relief of Jerusalem through armed combat.

This article draws on Cecilia Gaposchkin's work on the role of liturgical memorialization in defining the identity of a praying community. The memory of a sanctified crusader, such as Louis IX, was built and preserved by the community who chose to remember him liturgically. At the same time, that community, be it a religious order which the king has favoured during life, like the Franciscans and the Cistercians, or the royal court, infused his liturgical commemoration with identity markers. Ascribing to Louis the monastic virtues of a Cistercian, the compassionate endurance of St. Francis or the attributes of saintly Old Testament kings, the community built his liturgical memory in its own image. ${ }^{4}$ Similarly, the Franciscan friars of Jerusalem, appropriated the crusader liturgy for the liberation of the Holy Land and the figure of crusader kings, its liberators, in order to assert their role in the service of the Holy Sepulchre.

Likewise, liturgy was instrumental in the memorialization of the conquest of Jerusalem by the crusader army on 15 July $1099 .{ }^{5}$ Masses and processions were the main media by which the event of the recovery of the Holy City was integrated into the religious life and memory of Western Christianity and the Latin Kingdom of Jerusalem. ${ }^{6}$ The goal of the crusade was the liberation of the Holy Land ${ }^{7}$ and the conquest of Jerusalem was presented as a relief, a liberatio. ${ }^{8}$ The liturgical sanctification of war and its portrayal as a recovery continued throughout the last medieval centuries, culminating in an "explosion of dedicated war masses in the fifteenth century". ${ }^{9}$ Appropriating the memory of the historical event of the conquest of Jerusalem as an act of liberation and recovery was one of the essential strands of the crusading discourse that coloured the militant rhetoric of Latin Christendom towards Islam from the famous speech of Pope Urban II at Clermont (1095) until at least the fifteenth century, when hopes for a concrete recovery were abandoned. ${ }^{10}$ What Lee Manion calls "the narrative-generating power of crusading" $" 11$ has remained a staple of the Western war discourse. ${ }^{12}$

\footnotetext{
${ }^{2}$ Arce 1973, 76-9; del Buey and Alvi 2005, 11-12.

${ }^{3}$ Arce 1973, 86-92; Saletti 2016, 69-74.

${ }^{4}$ Gaposchkin 2013, 264-266.

${ }^{5}$ Gaposchkin 2014, 237-259.

${ }^{6}$ John 2015, 409-431.

${ }^{7}$ Constable 2001, 15.

${ }^{8}$ Linder 1990, 110-131.

${ }^{9}$ Gaposchkin 2017, 228-229.

${ }^{10}$ Manion 2014, 18.

${ }^{11}$ Manion 2014, 2.

${ }^{12}$ Theme explored thoroughly in Buc, 2015.
} 
The analysis of the two liturgical texts that I address in this article shows the friars appropriation of the crusader themes of "liberation", and "restoration". They borrowed prayers from the crusader liturgy and developed new forms of liturgical supplications for the deliverance of Jerusalem.

The first part of this article discusses the understanding of crusades in the milieu of the Franciscan friars of Jerusalem in the fifteenth century, and how the deeds of the crusader kings were memorialized in their writings. The second part is dedicated to the analysis of two liturgical texts, the "Votive mass for the recovery of the Holy Land" (Missa devota ad recuperandam Terram Sanctam) and the "Introit to the Holy Sepulchre of the Lord" (Ad Sanctum Sepulcrum Domini introitus).

\section{Memorializing the Crusades}

From the emergence of their order in the thirteenth century, Franciscan friars, alongside other mendicants, distinguished themselves as preachers of the crusade. ${ }^{13}$ The brethren became the champions of papal war efforts, which, alongside their involvement in papal and imperial politics, provided their opponents with many an argument for criticism and fed the antifraternal rhetoric. ${ }^{14}$

Indeed, many friars embraced enthusiastically the preaching of the crusade, the liturgy of war, and even leading the Christian army. In the fifteenth century, the rhetorical prowess of the Observant Franciscan Giovanni da Capestrano, displayed in sermons and masses celebrated on the battle field, is said to have so inflamed the poorly armed and trained crusading army gathered for the relief of Belgrade in 1456, that they managed to win an unexpected victory against the conqueror of Constantinople, Mehmet II. At least this is how contemporaries and posterity came to know Capestrano, the image of the firebrand crusading preacher being inherent to the textual and iconographic propaganda set in motion by the postulants of his sainthood. ${ }^{15}$

The lands conquered by crusaders in Syria and Palestine were presented to contemporaries as the recovered Christian inheritance in the Holy Land. ${ }^{16}$ The same discourse was appropriated by the friars upon their appointment as guardians of the Holy Places. Chronicles, treatises, diaries authored by Jerusalemite friars or by pilgrims guided by them around the Holy Land echoed the theme of conquest as liberation (liberatio) and recovery (recuperatio). One of the means through which the deliverance of Jerusalem and the recovery of the Holy Land was appropriated in the Franciscan recollection of the Holy Land was liturgy. In what follows, the theme of the recovery of the Holy Land in the liturgy of the Jerusalemite friars is approached in a twofold manner: first, by identifying the place ascribed to this endeavour in the Franciscan ministry in the Holy Land; secondly, by surveying the manuscript evidence.

To understand the various meanings ascribed by the friars to their Holy Land mission, specifically concerning its recovery, I refer to the testimony left by a friar, whose precise identity is unknown, but who visited the Holy Land and stayed with the friars in their Mount

\footnotetext{
${ }^{13}$ Maier 1994.

${ }^{14}$ Geltner 2012, 64-70.

${ }^{15}$ Housley 2004, 112-113.

${ }^{16}$ Manion 2014, 8-9.
} 
Sion convent in the mid-fifteenth century. ${ }^{17}$ He wrote for a prince who remained unnamed, but who very likely was Philip the Good, the Duke of Burgundy (1396-1467). ${ }^{18}$ Philip the Good championed himself as a crusader, a true scion of his ancestor Godfrey of Bouillon, about whose deeds he read extensively. ${ }^{19}$ The duke lavished the Jerusalem friars with his largesse: he sent alms and building materials for the repair of the Church of the Nativity in Bethlehem, built the chapel of the Holy Spirit on Mount Sion (destroyed shortly after its completion), and paid the debts of the Jerusalem friars. The friars of Mount Sion were involved in Philip the Good's crusading plans, and they sent him letters and messengers asking to mount an expedition to Palestine, to liberate the Holy Places. ${ }^{20}$ The relation between the anonymous friar and the Duke of Burgundy sets the writing of the former in the context of late medieval crusading projects. His exhortation to the Christian princes to liberate Jerusalem, part of his treatise on the Holy Land, was in the tradition of earlier Franciscan involvements in crusading projects. ${ }^{21}$

The friar's text is typical of the Holy Land histories and treatises produced by the friars of Mount Sion that frequently included crusader chronicles. Friars from the Jerusalem family used the crusader chronicles to draw up their own version of the "memoriale" of the holy war. ${ }^{22}$ Such a "memoriale" was integrated in the description of the Holy Land cum pilgrimage diary left by the anonymous friar.

By the fifteenth century, the memory of the crusader kings was integrated into the prayers for the recovery of the Holy Land. The visit to their tombs in the Church of the Holy Sepulchre triggered their recollection. ${ }^{23}$ In some pilgrimage accounts, the description of the royal funeral monuments was followed by a prayer for the recovery of the Holy Land, achieved by the warrior kings of yore. ${ }^{24}$ This remembrance tinged with nostalgia presented the inflections of the habitual crusading discourse, especially on the topos of the first crusader rulers of Jerusalem, Godfrey of Bouillon (1099-1100) and Baldwin I (1100-1118). As in the epitaphs adorning their tombs in the Church of the Holy Sepulchre, they were remembered as conquerors of the Holy Land. ${ }^{25}$

\footnotetext{
${ }^{17}$ Kohler 1911, 1-67.

${ }^{18}$ Kohler 1911, 1-2.

${ }^{19}$ Paviot 1996, 404, 410.

${ }^{20}$ Paviot 1996, 404, 410.

${ }^{21}$ Gautiér Dalché 2010, 87-95.

${ }^{22}$ Campopiano 2011, 331-333.

${ }^{23}$ The tombs mentioned most often by pilgrims were those of Godfrey and Baldwin, perhaps because of their spectacular epitaphs, commemorating them as conquerors of the Holy Land. See, for instance, the English pilgrim William Wey, who copied the epitaphs in the accounts of both his pilgrimages. Bukeley (ed.) 1857, 43, 68-69.

${ }^{24}$ For instance, one of the stations of the pilgrimage inside the Church of the Holy Sepulchre enumerated by the fifteenth-century vernacular poem The Stasyons of Jerusalem was at Godfrey of Bouillon and Baldwin's tombs. There the pilgrims prayed that Christendom be given again such princes, capable of recovering the Holy Land: "Than fond we in Galgatha so,/ Beryed worthily ther lyggys two:/ Godfrey of Boleyn and Baudwyn his brother./ Jhesu brynge thether sych two other;/ Than durst I sey that blyssed lond/ Schuld duell in Crystyn mennys hond”. Shuffelton (ed.) 2008, 338, 550.

25 " $†$ Hic iacet inclitus Dux Godefridus de Bulion, qui totam istam terram a[c]quisievit cultui chr[istiano]: cuius anima regnet cum Christo. Amen", and " $\uparrow$ Rex Balde(w)inus, Iudas alter Machab[a]eus, spes patri[a]e, vigor eccl[es]i[a]e, virt[us] utris[que]. Quem formidabant, cui dona, tribuna ferebant Cedar et [A]egypt[us], Dan ac homicida Damascus. Proh dolor! in modico clauditur in hoc tumulo". de Sandoli (ed. and Italian trans.) 1974, 54, 58. These are the epitaphs that fifteen-century pilgrims read. However, the original text of the epitaphs was changed after 1244, when the original tombs were destroyed by Khwarezmians. Folda 1995, 38-40, 74-75, 492, 506.
} 
In his chronicle of the crusades, "On the illustrious deeds of men named Baldwin, when they took back for Christians the Promised Land" (De gestis Balduinorum egregiis quando Terram promissionis christiano nomini vendicarunt), which he included in his treatise on the Holy Land, the anonymous friar recorded the memory of Godfrey of Bouillon "just as another Maccabee", (veluti Machabeus alter). ${ }^{26}$ The rhetorical genealogy of the Maccabees topos in the Western discourse on war is rich indeed. Comparing a warrior to Judas Maccabeus represented one of the finest forms of praise. The identification of the crusaders with the Maccabees is a constant of the Western holy war narrative. ${ }^{27}$ Moreover, the friar emphasized the connection between Godfrey and the Holy Sepulchre, which functioned as a memorial to the warrior who refused to be torn apart from Calvary and arranged to be buried at its foot. ${ }^{28}$

The end of the chronicle, and of the treaty, is telling for the clamorous appropriation of the crusader history into the Franciscan narrative. Viewed in the light of the probable relation connecting this friar to the circle of the duke of Burgundy, Philip the Good, his pleading for the Holy Land cause can be seen as representative of the treatises that fed the crusading rhetoric in the latter part of the fifteenth century. ${ }^{29}$ The loss of Jerusalem is explained in the usual manner, as the result of inner Christian dissent and the military might of Saladin. The author phrased the loss in terms of estrangement, a choice of words customary to the recuperatio Terre Sancte narrative. In this narrative, the reference to the loss of the Holy Land was phrased in the words of the Book of Lamentations: "the Lord's inheritance was given to strangers" (versaque est Domini hereditas ad alienos) (Lamentations 5,2), a means of othering Muslims by reference to biblical exempla of foreigners who deprived the elected of their inheritance. $^{30}$

The call for recovery was intrinsic to this type of narrative. And this is precisely how the anonymous friar chose to end his treatise, and the chronicle, with a plea to the Christian princes, and a prayer, so that they would unite in the reconquest of the Holy Land, understood as recovery: "to take and give us back" (revendicent et restituant nobis). ${ }^{31}$

\footnotetext{
26 "Namque cum undique barbaris hostibus vallatus esset, quoniam et ab oriente Arabes, Moabitas, Amonitas, ab occidente Saracenos, a meridie Idumeos, Philisteos Egyptiosque confinio haberet, veluti Machabeus alter, divino satius quam humano fretus presidio, perrexit primum contra Saracenos, quos haud diuturno bello prosternens, Joppem ea tempestate munitissimum oppidum cepit, posteaque Ramulam que et magnitudine et munitionibus satis ampla eo presertim tempore erat". Kohler 1911, 55.

${ }^{27}$ Morton 2010, 275-293; Signori 2012, 15-21; Lapina 2012, 149-150.

28 "Qui et se ad radices Calvarie montis sepelliri mandavit, utpote qui Christi amore dillectus, adversus infideles pugnacissime dimicaverat dum viveret, nec moriens pateretur quod poterat ab illo seiungi, namque et eius marmoreum sarch ofagum ibi etiam hodie cernimus". Kohler 1911, 55.

${ }^{29}$ For pleas for crusade in fourteenth-fifteenth centuries political discourse, see: Tyerman 1985, 25-52; Weiler 2003, 136.

${ }^{30}$ Tolan 2002, 94 .

31 "Octogenos enim et octo annos hi clarissimi reges tantummodo regnavere, a millesimo quidem nonagesimo Christi annno usque ad annos mille centenos octoginta septem eorum duravit imperium. Qua tempestate orto inter posteros dissidio, a Saladino Babilonie soldano potentissimo facili contriti sunt, versaque est Domini hereditas ad alienos. Quam utinam christiani principes velint aliquando contendere et eniti et revendicent et restituant nobis, quo etemur in ea in letitia cordis nostris". Kohler 1911, 59.
} 


\section{The Holy Land Franciscan liturgy of war}

The testimony of the anonymous Franciscan exemplifies the integration of the memory of the crusades into the Minorite perception of the numinous space to which they were the appointed guardians ${ }^{32}$. The theme of the recovery was also memorialized in the liturgy of the Jerusalemite friars. Among the liturgical manuscripts preserved today in the Biblioteca Generale della Custodia di Terra Santa, there are some samples of what the Franciscan Jerusalemite liturgy of war might have looked like. The manuscript witnesses we have for the liturgy of the recovery of the Holy Land consist in two standard missae ad recuperandam Terram Sanctam and of an introit, the Ad Sanctum Sepulcrum Domini introitus, which appears to be a particularity of the Jerusalemite liturgy. The presence of these liturgical texts is remarkable. Most of the Franciscan liturgical books were imports from Europe, brought by the friars themselves or bestowed on them by European donors. ${ }^{33}$ Upon thorough investigation of the medieval liturgical manuscripts held today in the Biblioteca Generale della Custodia di Terra Santa, I can remark that very few alterations were done to reflect their use in Jerusalem. As most Franciscan convents, the Jerusalem friars followed the liturgical usage of Rome, namely of the papal chapel, and adopted the feast days of the diocese of Rome already in St. Francis's day. ${ }^{34}$ The friars scarcely altered or even annotated their liturgical documents. Most alterations were done to include newly canonized Franciscan saints in the Sanctorale. That is why, the two liturgical pieces discussed here are all the more remarkable. They were added in Jerusalem to older missals brought from Europe, in response to local needs. The friars lived in Jerusalem under Muslim rule and these liturgical texts express their militant prayer for the liberation of the Holy Sepulchre, for the return of the age of the crusader kings.

\section{The Missa devota ad recuperandam Terram Sanctam of the Jerusalem Franciscans}

In his study on the Franciscan Custody of the Holy Land as a keeper and intermediary of the memory of the Holy Places, Michele Campopiano has pointed out the pivotal role played by historico-geographical compilations produced or copied in the friars' convent on Mount Sion in shaping the late medieval Western view on the Holy Land. ${ }^{35}$ Similarly, the friars' liturgical manuscripts open a window into their appropriation of the theme of recovery through the rituals they carried out in the Holy Land.

Two manuscripts from the Franciscan Library in Jerusalem, MS MIN. 1 olim SF1278 and MS MIN. 2 olim ZzV19 ${ }^{36}$, preserve the text of the Missa devota ad recuperandam Terram Sanctam: ${ }^{37}$

\footnotetext{
${ }^{32}$ On Jerusalem's numinous status, see Tyerman 2007, 68.

${ }^{33}$ The latest description of the liturgical fund and its catalogue were produced by Sara Cibin. Cibin 2016, 19-21, 23-39.

${ }^{34}$ Congar 1961, 107-108.

${ }^{35}$ Campopiano 2014, 49-69.

${ }^{36}$ A description of the two manuscripts in: Bux 1990, 40-47.

${ }^{37}$ Transcribed from Jerusalem, Biblioteca della Custodia di Terra Santa, MS MIN.2 olim ZzV19, 122r (modern numbering).
} 
Deus, qui amirabili providentia cuncta disponis, te suppliciter exoramus, ut terram quam unigenitus filius tuus proprio sanguine consecravit, de manibus inimicorum crucis potenter eripiens restituas cultui christiano, vota fidelium ad eius liberationem instantium misericorditer dirigendo in viam salutis eterne. Per eum. ${ }^{38}$

\section{Secreta}

Deus, qui in singulari corporis tui hostia totius mundi solvisti delicta, in hac oblatione placatus, terram pretiosi sanguinis tui aspersione sacratam, expulsa omni sevitia potestatis adverse, catholice restituas libertati. Per Dominum.

\section{Post communionem}

Sacris repleti muneribus quesumus, Domine Deus noster, ut terram presentie tue dicatam ab hostium tuorum eripias servitute, ut ea redita te propitiante cultui tuo, obsequia tibi grata populus tuus in ea devotus impendat. Per Dominum nostrum Ihesum Christum Filium Tuum, qui vivit et regnat in unitate Spiritus Sancti Deus per omnia secula seculorum. Amen.
God, who, through wonderful foresight, ordain all, we pray you humbly that, taking the land consecrated through the very blood of your only-begotten Son from the hands of the enemies of the cross, restore it to Christian worship, leading the sacrifices of the faithful to its rapid deliverance, on the way of eternal life. Through him.

The secrets

God, who through the unique sacrifice of your body, have absolved the sins of the entire world, placated by this offering, chase out from the land sanctified by the shedding of your precious blood the savageness of the enemy power, and restore it to universal freedom. Through the Lord.

Post communion

After we have received the sacred gifts, we ask you, Lord our God, to deliver from the slavery of your enemies the land that is called yours, so that, through your grace, is restored to your worship and your devout people serve you in it with gratitude. Through our Lord, Jesus Christ, your Son, who lives and reigns with you in the unity of the Holy Spirit forever and ever. Amen.

The prayers of this mass were added to an older missal, probably in the fourteenth century. ${ }^{39}$ The same hand added this mass to MS MIN. 1, also an older missal. Liturgical instructions, the secreta before Deus, qui in singulari corporis, the mention that the Sacris replete muneribus should be recited after Communion, and the title of the mass, Missa devota ad recuperandam Terram Sanctam, were added in a different but contemporaneous hand.

If the Christian conquest of Jerusalem triggered its liturgical memorialization, so did its loss to Saladin on 2 October 1187. The liturgical clamours for the loss of Jerusalem and supplication for its recovery and the Holy Land masses originated either in papal initiative or in that of the religious orders. ${ }^{40}$ They were usually connected to calls for a new crusade or triggered by the threat of the loss of yet other Christian lands. ${ }^{41}$ Already in November 1187, Gregory VIII followed his encyclical letter Audita tremendi, which lamented the loss of Jerusalem and renewed the call for crusade, with the introduction of special liturgy for the liberation of the Holy Land. ${ }^{42}$ Under Innocent III, prayers for the liberation of the Holy Land became a permanent liturgical feature. In his bull, Quia maior (1213), the pope arranged for monthly processions, where the participants were instructed to pray thus: "asking that the merciful God should take away the opprobrium of this confusion, freeing from the hands of the pagans that land in which he established all the sacraments of our redemption, restoring it

\footnotetext{
${ }^{38}$ In MS MIN. 1, this part is marked as the oratio (the collect). Jerusalem, Biblioteca della Custodia di Terra Santa, MS MIN.1 olim SF1278, 143r (modern numbering).

${ }^{39}$ The original manuscript is dated by Bux to the second half of the thirteenth century, by Gumbert to the first half of the fourteenth, by Cresi to the second half of the fourteenth century, by Cenci to the end of the fourteenth century. Bux 1990, 45; Gumbert 1991, 485; Cresi 1963, 470-471; Cenci 1991, 488. Bux is the only one to date the later additions to "the end of the $15^{\text {th }}$ c. or after". Bux 1990, 47, n.2. However, the Missa devota ad recuperandam Terram Sanctam is in a hand different from the pieces on which Bux has based his dating.

${ }^{40}$ Maier 1997, 631-632.

${ }^{41}$ Linder 2003, 26-27,186-189, 355-356.

${ }^{42}$ Folda 2012, 128.
} 
to the Christian people to the praise and glory of his holy name". ${ }^{43}$ His immediate successor, Honorius III, continued to instil liturgical support for the crusade, with special prayers and responsories during daily masses. Perhaps a measure of the popularity achieved by crusader liturgy is given by the inclusion of an "order of the liturgical service for the deliverance of the Holy Land from the enemies of the faith" (ordo pro liberatione terre sancte a fidei inimicis), in fact a copy of the liturgical instructions prescribed by the Quia maior, in the Roman Pontifical of William Durandus. ${ }^{44}$

The Jerusalem witnesses of the missa ad recuperandam Terram Sanctam present the special prayer assigned to this observance by the Quia maior, namely the collect Deus qui admirabili providentia cuncta disponis. ${ }^{45}$ In Quia maior and subsequent papal instructions, this prayer was preceded by the chanting of Psalm 78: "Oh God, the gentiles have come into your inheritance" and Psalm 68: "Rise up, O God, and your enemies will scatter, and those who hate him will flee from his face". "However, these psalms do not feature in the form of the mass recorded by the Jerusalem manuscripts. Instead, the set of prayers in the friars' mass for the recovery of the Holy Land correspond to what Amnon Linder has defined as "the sets of three mass prayers", consisting of the three dedicated Holy Land prayers, which, associated with any type of mass, transformed it into a Holy Land votive mass. ${ }^{47}$ These prayers are: the collect Deus qui admirabili, the secret Deus qui in singulari corporis tui, and the postcommunion Sacris replete muneribus quesumus. ${ }^{48}$

The contents evolve around the themes of recovery and liberation. God is supplicated so that Christians prevail over their enemies and the Holy Land "be restored to Christian worship" (restituas cultui Christiano), "restored to your worship" (redita cultui tuo). Echoing the language of Quia maior, ${ }^{49}$ the reason of what makes this Holy Land holy and the inheritance of Christians is stated both in the collect and in the secrets: it was the place where Christ shed his blood, a sacrifice that made the land holy (terram quam unigenitus filius tuus proprio sanguine consecravit; terram pretiosi sanguinis tui aspersione sacratam). This very consecration called for liberation, the aim of the sacrifices undertaken by the faithful for its deliverance (vota fidelium ad eius liberationem). In this paradigm, freedom is universal and Christian (catholice restituas libertati) and opposed to the slavery and the savageness (ab hostium tuorum eripias servitute; sevitia potestatis adverse), that were traditionally one of the trademarks of the Muslim enemy. ${ }^{50}$

The theme of the "universal freedom" (catholica libertas) evoked the necessity of war, which, in the Western Christian discourse on violence, represented the means for securing the liberty of the Church (libertas ecclesie) or of Christianity (libertas christiana) ${ }^{51}$ The freedom of the Church, as ultimate aim for engaging in battles against the enemies of the faith (pro libertate ecclesie, pro liberatione ecclesie), was a recurrent theme of the crusading narrative.

\footnotetext{
${ }^{43}$ Bird, Peters and Powell 2013, 111.

${ }^{44}$ Maier 1997, 637.

${ }^{45}$ Bird, Peters and Powell 2013, 112.

${ }^{46}$ Bird, Peters and Powell 2013, 111-112.

${ }^{47}$ Linder 2003, 97-98, 103.

${ }^{48}$ Linder 2003, 106.

${ }^{49}$ Bird, Peters and Powell 2013, 112.

${ }^{50}$ Tolan 2002, 94

${ }^{51}$ Buc 2015, 213-215.
} 
This is how, at the other fringes of Europe, the crusade and victory against the "heretic" Stedinger was liturgically commemorated immediately after their defeat in $1234 .^{52}$ Holy warfare, in this case a new crusade, for the realization and success of which this mass was created, became legitimate as a means of ensuring the liberty of Christians in the reconquered Holy Land.

The Franciscan-led pilgrimage in Jerusalem had a standard liturgy, which the brethren imposed through pilgrimage booklets, the "Pilgrimages of the entire Holy Land" (Peregrinationes totius Terrae Sanctae). By the second half of the fifteenth century, they were printed in Venice in the dozens and sold to pilgrims at veritable book fairs before they sailed to the Holy Land. ${ }^{53}$ These booklets contained the itinerary, indulgences and prayers attached to the Holy Places. ${ }^{54}$ However, they did not include this special mass for the recovery of the Holy Land.

Yet, its presence in a fifteenth-century manuscript in the Biblioteca Colombina in Seville, MS 5-2-46, suggests that the prayers for the relief of the Holy Land entered some pilgrimage booklets, albeit not in the standardized version. ${ }^{55}$ With the dimensions of a small portable book $(166 \times 120 \mathrm{~mm}),{ }^{56} \mathrm{MS} 5-2-46$ contains Jordan of Quedlinburg's expositio on the Passion, ${ }^{57}$ the "Lauds and prayers for the Holy Land" (Laudes et orationes Terre Sancte), followed by a standard list of the Holy Places and their indulgences. ${ }^{58}$ Completed with some crude drawings of the Arma Christi and Mary of Sorrows (f. 1v), and of Christ's prayer in the Garden of Gethsemane (f. 8v) this was probably someone's personal prayer book. The Laudes et orationes Terre Sancte are introduced by the clarification that these are the prayers of the Holy Land pilgrimage. Intriguingly, it mentions that this pilgrimage could be done "both in spirit and in body". 59 Regardless of whether they were used in the Holy Land pilgrimage made in corpore or in spiritu, the prayers opening the pilgrimage are the supplications for the recovery of the Holy Land:

\footnotetext{
${ }^{52}$ Cassidy-Welch 2013, 165, 168-170.

${ }^{53}$ Trovato 2015, 191-196.

${ }^{54}$ The synopsis of antiphons put together by Elena Niccolai and Martina Cita based on the processional prayers included in guidebooks authored by pilgrims or in the standard Peregrinationes totius Terrae Sanctae printed in Venice 1479 constitutes a solid database for the liturgical texts found in booklets circulated among pilgrims. Niccolai 2015, 205-258; Cita 2015, 259-308.

${ }^{55}$ Sáez Guillén 2002, 135-6.

${ }^{56}$ Sáez Guillén 2002, 135.

${ }^{57}$ Seville, Biblioteca Colombina, MS 5-2-46, 1v-53r.

${ }^{58}$ Seville, Bibliteca Colombina, MS 5-2-46, 69v-53r (Suprascripte sunt peregrinationes Terre Sancte que a modernis peregrinis visitantur).

59 "Nota per has laudes seu orationes Terre Sancte poteris ipsam Terram Sanctam tam in spiritu quam in corpore devote visitare". Seville, Biblioteca Colombina, MS 5-2-46, 53r.
} 
Et primo legas devote psalmum XXXV.

Benedixisti Domine terram tuam etc. Gloria Patri etc.

$V$. Portio mea, Domine, sit in Terra viventium.

\section{Oratio:}

Deus qui admirabili prudentia cuncta disponis, te suppliciter exoramus, ut terram quam unigenitus tuus Dominus noster Ihesus Christus proprio sanguine consecravit, de manibus inimicorum crucis potenter eripiens, restituas cultui christiano, vota fidelium ad eius liberationem instancium misericorditer in viam salutis eterne dirigendo. Per eum qui venturus est iudicare.

\begin{abstract}
You should read first Psalm 35.
Lord, you blessed your land, etc. Glory to the Father etc.

$V$. My lot, Lord, is in the land of the living.

Collect:

God, through wonderful foresight you ordain all. We humbly ask you that, forcefully tearing away from the hands of the enemy of the cross the land consecrated by the blood of Your only-begotten Son, our Lord Jesus Christ, return it to Christian worship, and mercifully reward the sacrifices of the faithful leading them to eternal life. Through him who is coming to judge [us].
\end{abstract}

These introductory prayers feature the same collect, the Deus qui admirabili, as the Missa devota ad recuperandam Terram Sanctam of the Jerusalem manuscripts. However, the prayers in the manuscript from the Biblioteca Colombina differ in the addition of Psalm 34, the antiphon Benedixisti Domine terram tuam and the versicle Portio mea. ${ }^{60}$ The verses of the psalm, the antiphon and the versicle were concordant with the collect, in words asking for God's assistance to defeat the enemies of the just and begging for the recovery of Christians' lost inheritance.

\section{The Ad Sanctum Sepulcrum Domini introitus}

Like the Missa devota ad recuperandam Terram Sanctam, this liturgical piece was added to MS MIN.2 olim ZzV19, a thirteenth-fourteenth century missal used by the Jerusalem friars. Nicola Bux dated the addition of the introit to the "the end of the $15^{\text {th }} \mathrm{c}$. or later" based on another addition, the In Transfiguratione Domini introitus. The Mass of the Transfiguration, celebrated by the Eastern Churches, was adopted in the Roman Church only in $1457 .{ }^{61}$ Both introits were added in the same hand. Thus, the Ad Sanctum Sepulcrum Domini introitus probably entered the friars' missal in the second part of the fifteenth century.

This Jerusalem manuscript appears to be the only witness for the liturgical scheme presented by the Ad Sanctum Sepulcrum Domini introitus. A likely explanation for this conspicuous singularity might be that this introit was not included in the standardized Peregrinationes totius Terrae Sanctae. Its absence from these standard guidebooks suggests that, perhaps because of its seditious contents, asking for the liberation of the Holy Land, it was left out by the friars from the booklets they circulated. Instead, we find it in one of their missals, used within the confines of churches.

The liturgical occasion for the use of this introit can be surmised exclusively from its contents, as there are no liturgical instructions regarding the feast to which it was ascribed. Given its focus on the Tomb of Christ, it is tempting to associate it with the ceremony of the Deposition of Christ on Good Friday, during which the veneration of the Cross and Christ's 'buri-

\footnotetext{
${ }^{60}$ Psalm 35, Iudica, Domine, nocentes me, expugna impugnantes me. Antiphon Benedixisti, Domine, terram tuam (Feria V and VI per annum). Hesbert (ed.) 1968, 89. The antiphon Portio mea, Domine, sit in terra viventium was ascribed to the Feria VI per annum. http://cantus.uwaterloo.ca/search?t=portio+mea+domine+sit [last accessed: December 2018].

${ }^{61}$ Bux 1990, 47 n 2.
} 
al' in the Easter sepulchre occurred. ${ }^{62}$ However, the presence of the Alleluya excludes this option, since this expression of jubilation, alongside the angelic hymns Te Deum and Gloria was absent from the Liturgy of the Quadragesimal time. ${ }^{63}$

Moreover, as becomes clear from the first line, the introit commemorated the sepulchre as the place of the Resurrection rather than the memorial of Christ's suffering and death. The first line refers to the worship of the Holy Sepulchre as a Christian duty: "It is right that we worship the tomb of Our Lord Jesus Christ, in which our strength, life and consolation lie, through which we were reborn and baptized". ${ }^{64}$ Margot E. Fassler has shown the versatility of the Nos autem introit. Initially an antiphon in the liturgy of the feasts of the Cross and Holy Week, in the later Middle Ages Nos autem was adapted and altered to create new liturgical pieces. ${ }^{65}$ The creator of the Ad Sanctum Sepulcrum Domini introitus rooted his piece of Hagiopolite liturgy in the liturgical tradition of the Nos autem, well-known to the faithful from the antiphons for the feast days of the Invention and Exaltation of the Cross. ${ }^{66}$

The reoccurrence of the Alleluya, the Paschal acclamation par excellence, and the introductory verses all seem to place it in a time of liturgical jubilation, very likely the Paschal time. This impression is reinforced by the reading taken from the Gospel of St. Matthew about the empty tomb and the constant reference to the sepulchre as the memorial of the Resurrection. However, the inclusion of the reading from the prophet Isaiah (Is. 53, 1-9) would place it in in the Advent period. This point is clarified by research done into the crusader liturgy of the Liberation of Jerusalem, in which the Book of Isaiah was substantially used in these newly created liturgical forms that celebrated the new advent of Christians in the Holy Land. ${ }^{67}$

There was a "Mass for the veneration of the Holy Sepulchre" (Missa in veneratione Sancti Sepulcri) introduced by crusaders in the liturgy of the Church of the Holy Sepulchre. This mass was transmitted with a chronicle of the first crusade, the anonymous "The deeds of the Franks and the other pilgrims to Jerusalem" (Gesta francorum et aliorum hierosolimitanorum $){ }^{68}$ This crusader mass resembles the introit here discussed on many points: it conserves the format of a liturgical piece specially composed for the Holy Sepulchre that was understood as object of veneration in the historical setting of Jerusalem and as cenotaph of the entire Christendom hoping for resurrection. Common is also the understanding of the Sepulchre in a typological framework, as the place where the prophecies of the Old Testament were fulfilled. However, the mass and the introit differ on a crucial point: they have different liturgical contents. ${ }^{69}$ The introit is remarkably original, with its mix of devotion and bellicose

\footnotetext{
${ }^{62}$ Duffy 2005, 29-30.

${ }^{63}$ Hughes 1982, 246.

64 "Nos autem venerari oportet sepulcrum Domini Nostri Yhesu Christi, in quo est virtus, vita et consolacio nostra, per quem renati et baptiçati sumus". Jerusalem, Biblioteca Generalle della Custodia di Terra Santa, MS MIN.2 olim Zz V 19, 123.

${ }^{65}$ Fassler 2011, 22-27.

${ }^{66}$ Antiphon for the feast days of the Invention and Exaltation of the Cross: "Nos autem gloriari oportet in cruce Domini nostri Jesu Christi, in quo est salus, vita, et resurrectio nostra, per quam salvati et liberati sumus". Hesbert (ed.) 1970, 308.

${ }^{67}$ Linder 1990, 113-120; Gaposchkin 2016, 36-7, 40-41.

${ }^{68}$ Hill (ed. and trans.) 1926, XXXVIII.

${ }^{69}$ See the prayers of the Missa in veneratione Sancti Sepulchri in Hill (ed. and trans.) 1926, 102.
} 


\section{supplication. But first, given the fact that it was not previously studied or edited, a short map- ping of the liturgical scheme may be helpful:}

\section{Ad Sanctum Sepulcrum Domini introitus ${ }^{70}$}

Nos autem venerari oportet sepulcrum

$V$. Quam dilecta tabernacula tua, Domine

Ps 84, 2-3 In Dedicatione Ecclesie ${ }^{71}$

$V$. Gloria Patri etc.

\section{Oratio:}

Omnipotens sempiterne Deus, qui per unigenituum tuum pro nobis morientem et in sepulcro dulciter quiescentem mortis dominium devicisti, tribue nobis opera mortis repellere et ad vitam semper tendere sempiternam, ut gloria resurrectionis devoti efficiamur, et in futuro celesti gaudio divino munere rapiamur. Per eum.

Lectio Ysaie prophete

Is $53,1-9$ in the Ante-Communion of Good Friday service ${ }^{72}$

\section{Alleluya}

O spelunca dignissima tuis sanctis visceribus ut figurarum septima vite librum clausisti, spes ad vitam fidelibus per te data surgentibus, qui et tu peperisti.

\section{Alleluya}

Hic insignis ac cubitus troni imprialis odore fragrat celitus, afflatus prophetalis inpletus, nam corrupcio abest et resoluti organi virginali.

\section{Alleluya}

O rex Deus fortissime, tui pondus iudicii exerce potentissime, super gente ferali iube nobis restitui locum sacrati tumuli, brachio virtuali.

Sequitur prosa:

$\mathrm{O}$ insignis sepultura

Secundum Mattheum

Matt. 27, 62-66

\section{Offertorium:}

$\mathrm{O}$ splendor glorie, cuius corpus supinum accubuit in pulvere labem pellens infectionis squalide qui tu non sensisti, tu consepultos resuscita tecum, in tremendo examine ad vitam qui promisisti.

\author{
It is right that we worship the tomb \\ $V$. Your noble altars, Lord \\ $V$. Glory to the Father \\ Collect:
}

O Almighty and everlasting God, who, through your Son, who died and was laid to rest in the sepulchre, have triumphed over death, grant us that we ward off the work of death, so that we devoutly achieve the glory of the resurrection, and, through divine favour, are received in the joy of heaven. Through him.

\section{Lesson from the prophet Isaiah}

\section{Alleluya}

O most noble cave, the same way you enclosed in your depths the book of the seven figures of life, hope unto life was given through you to the raising faithful, whom you had born.

\section{Alleluya}

The Heaven is fragrant with the scent of this illustrious imperial throne [the Tomb]. The longing of the prophets fulfilled, now free of corruption, is restored to its virginal state.

\section{Alleluya}

O King Almighty God, exercise the strength of your judgement, o, all-powerful, and order that we prevail over [this] ferocious people. Through the fighting arm, restore to us the place of the Holy Tomb.

Prose:

O noble tomb

Lesson from the Gospel according to Matthew

Offertory:

O glorious splendour, whose body laid in dust, you who were not touched by the foul stain, on the day of your terrible judgement resurrect with you, to the life that you promised, those buried with you.

\footnotetext{
${ }^{70}$ Transcribed from Jerusalem, Biblioteca Generale della Custodia di Terra Santa, MS MIN.2 olim Zz v 19, 123r-125r.

${ }^{71}$ Hesbert 1970, 362.

${ }^{72}$ Tyrer 1932, 123.
} 
Sanctus $^{73}$

Deus qui in figuram his altaris tuum sacratissimum corpus in sepulcro includi permisisti, concede propicius ut huius oblacionis misterio nos et de viciorum exire sepulcro et tecum consepeliri facias. Qui cum.

O radix Iesse pullulans de corde terrenorum, qui stas semper ut adiuvans, in figura semper glorificans sepulcrum gloriosum.

Alleluya

Post communionem:

Deus, qui pro nobis filium tuum mortuum ac sepultum resurrexisse fecisti, concede propicius ut nobis ad memoriam sue vivifice sepulture recurentibus per sancta que sumpsimus secum consepeliti, cunctis malis actibus moriamur. Per eundem.
The Holy

God, who have allowed your most holy body to be laid in the figure of this altar, mercifully grant us that, through the mystery of this sacrifice, we are freed from the sepulchre of vices and buried together with you. Who [reigns] with.

Oh, root of Jesse, sprouting from the middle of the earthly dwellers, ever-helpful you are always present in the figure of this glorious sepulchre.

\section{Alleluya}

\section{Post communion:}

God, who, for our sake, raised your dead and buried Son, mercifully grant that we, who come to the memorial of his life-giving sepulchre, receiving the sacred [sacraments], are buried with him and dead to all evil. Through him.

Its contents suggest that this introit might have been created for the Easter celebrations. It may well have been meant to accompany the pilgrims' devotions when entering the Edicule or belonged to a special mass of the Holy Sepulchre, perhaps the mass that was said by a friar prior to the dubbing ceremony, which took place in the Edicule of the Holy Sepulchre. ${ }^{74}$ This church, seen as the place of the Resurrection, dictated the type of liturgical memorialization. When Latin pilgrims entered the Church of the Holy Sepulchre, the mass celebrated inside the Sepulchre was the Mass of the Resurrection, even if they visited Jerusalem in July. ${ }^{75}$ Descriptions left by pilgrims, such as the Evagatorium produced by the Dominican Felix Fabri after his two pilgrimages, in 1480 and 1483-1484, mentioned the singing of Paschal hymns and the repetition of the jubilant Alleluya when entering the Sepulchre. In fact, the entire ceremony seemed to emulate the Easter festivities. ${ }^{76}$ With its focus on the Resurrection, this liturgical piece of Franciscan origin was in the tradition of earlier Latin liturgical practice at the Church of the Holy Sepulchre. As Sebastián Salvadó has shown, the crusader liturgy of the Church of the Holy Sepulchre was reformed by the Latin Patriarch Fulcher of Angoulême, who changed the focus of the celebrations on Easter ceremonies and the theological theme of the Resurrection. ${ }^{77}$

The prayers speak precisely of the memory of the Resurrection. Typology provided the interpretative framework that connected the Edicule (the physical space) with its function as memorial of the Resurrection. Within this exegetical logic, Isaiah's vetero-testamentary prophecy of the luxurious root sprouting out of the thirsting land is echoed in the Eucharistic prayer by the image of the "root of Jesse" sprouting out of human hearts. Here, the creator of this introit played on the memorable words of one of the great antiphons of the Latin liturgy,

\footnotetext{
${ }^{73}$ Added later in a different hand.

${ }^{74}$ On knighting at the Holy Sepulchre under Franciscan guidance, see de Gennes 1995, 219-338.

${ }^{75}$ See, for instance, the account by Fabri in Hassler (ed.) $1843-1849$, vol. 1, 312; vol. 3, 19.

76 "Igitur cantor festiva et iucunda voce hymnum paschalem: Ad coenam agni providi etc. Inchoavit, et cum isto cantu processimus, et ad dulcissimum Domini Iesu sepulchrum venimus, et ante eum cantica paschalia cum creberis Alleluia personavimus, cum tanto gaudio, et forte cum maiori, ac si festus dies Paschae post laboriosam et tristem quadragesimam advenisset". Hassler (ed.) 1843, vol. 1, 309.

${ }^{77}$ Salvadó 2017, 403-420.
} 
the $O$ radix Jesse, one of the so-called 'Great Os' ${ }^{78}$ However, he changed the words of the well-known antiphon, ${ }^{79}$ connecting the image of the life-giving tree to the sepulchre ${ }^{80}$. Moreover, in a striking exercise of typological inversion, in the prose $O$ insignis sepultura, Christ's tomb is referred to as the virginal womb of the Mother of God:

Hic est tumulus regalis, Typum tenens virginalis Matris Dei uteri.
This is the royal tomb,

That holds the figure of

God's Mother virginal womb.

The same typological inflection occurs in another prayer:

Hic insignis ac cubitus troni imperialis odore fragrat celitus, afflatus prophetalis impletus, nam corruptio abest et resoluti organi virginalis.
The Heaven is fragrant with the scent of this illustrious imperial throne [the Tomb]. The longing of the prophets fulfilled, free from corruption, is now restored to its original state.

As in other cases in the liturgy of the Holy Sepulchre, for instance in the Visitatio Sepulchri ritual, ${ }^{81}$ the indicative power of the demonstrative hic was used to emphasize that here, at this very Sepulchre, the prophecies of the Old Dispensation were fulfilled in the Risen Christ, who left the tomb unspoiled, like the virginal womb. In this as well, the friars followed in crusader steps. In his popular history of the Outremer, Jacques de Vitry (thirteenth century) wrote that the addition of the demonstrative pronoun hoc was the exclusive liturgical privilege of the Augustinian canons, whom the crusader kings appointed to serve at the Holy Sepulchre. They complemented the hortative power of the demonstrative by pointing towards the Tomb, indicating the very place of the Resurrection. ${ }^{82}$

The fragment most relevant to the topic treated here is the collect $O$ rex Deus fortissime, containing the supplication for the recovery of the Holy Land:

O rex Deus fortissime, tui pondus iudicii exerce, potentissime, super gente ferali iube nobis restitui locum sacratum tumuli, brachio virtuali.
O King Almighty God, exercise the strength of your judgement, o, all-powerful, and order that we prevail over [this] ferocious people. Through the fighting arm, restore to us the place of the Holy Tomb.

It invoked God's justice to allow Christians to reconquer, "arms in hand" (brachio virtuali), the sepulchre of Christ. The intrinsic connection between liberation and the necessity of war followed the usual patterns of crusading discourse, in which one called for the other.

\footnotetext{
${ }^{78}$ Seven or twelve antiphons with texts taken from the Old Testament, all beginning with the word 'O'. They belonged to the liturgy of ferial days before Christmas. Hughes 1982, 73, 366.

${ }^{79}$ The words of the $O$ radix Jesse antiphon run: "O radix Jesse qui stas in signum populorum, super quem continebunt reges os suum, quem gentes deprecabuntur; veni ad liberandum nos, iam noli tardere”. Hesbert 1968, 375.

${ }^{80}$ In fact, the entire structure of this liturgical piece calls to mind the cadence of the "O Antiphons", with short prayers, $O$ spelunca dignissima, $O$ rex Deus fortissime, $O$ insignis sepultura, $O$ splendour glorie, $O$ radix Iesse, separated by the Alleluya.

${ }^{81}$ Shagrir 2010, 57-77.

82 "Cum autem per mundum universum a fidelibus dicatur: 'Surrexit Dominus de sepulchro qui pro nobis pependit in ligno', soli canonici ecclesie Resurrectionis Dominice speciali gaudent prerogativa dicentes et ad oculum demonstrationem facientes: 'Surrexit Dominus de hoc sepulchro'. Similiter in evangelio paschali cum dicitur: 'Surrexit, non est hic!' diaconus qui legit evangelium digito demonstrat dominicam sepulturam”. de Vitry 2008, 242, 244.
} 
Referring to the Muslim lords of the Church of the Holy Sepulchre as a "beastly people" (gens feralis) pertained to the usual formulae of crusading rhetoric. Liturgically, it echoed the collect of one of the most widespread types of Holy Land masses, clamor 3 in Linder's taxonomy, which asked that: "The people who confide in their savageness are subdued through the strength of your right hand" (Te gentes quae sunt in feritate confidunt potentiae tuae dextera compriantur). ${ }^{83}$ The author of the introit very likely drew on the tradition illustrated by this clamor but also on a more ancient use. The call for "the nations that trust in their fierceness" (gentes quae in sua feritate confidunt) to be brought to obedience by the Christian ruler was part of the Intercessory Prayers following the reading of the Gospel in the Good Friday service. ${ }^{84}$ The same plea for divine help against the alien 'savageness' became part of the crusader contra paganos mass in the eleventh century. ${ }^{85}$

This particular collect, which transforms the introit into a supplication for the liberation of the Holy Land, seems to have been borrowed by its creator directly from Urban II, very likely from one of the versions of his speech at Clermont in 1095. Many of the compilations produced and copied by the friars in Jerusalem in the fourteenth-fifteenth centuries included large passages from various crusader chronicles. ${ }^{86}$ Although there is no exact account of Urban II's speech at Clermont, various versions were recorded by crusader chroniclers. ${ }^{87} \mathrm{~A}$ formula almost identical to this collect appears in a letter sent by Urban II to the monks of Vallombrosa in $1096{ }^{88}$ The pope discouraged the Benedictines of Vallombrosa to take up arms for the liberation of the Holy Land. Instead, he emphasised that this goal could be achieved by the knights joining the expedition, who could restore the Holy Land to Christians, using their arms to defend the "savageness of the Saracens":

We encourage knights to go on this expedition, who, through their arms, could put an end to the savageness of the Saracens and restore Christians to their former liberty. ${ }^{89}$

Thus, it appears that the creator of the introit borrowed from crusader propagandistic literature, of which a rich variety could be found on the shelves of the friars' library on Mount Sion, to convey the urgency of the introit's appeal for the liberation of the Holy Land.

This paper argues that the Ad Sanctum Sepulcrum Domini introitus is a liturgical piece created very likely in Jerusalem by one of the friars of Mount Sion. With its focus on the Sepulchre as a memorial of the Resurrection and type of virginal incorruptibility, the introit comes close to the crusader Missa in veneratione Sancti Sepulcri. However, they have very different liturgical contents, characteristic of dramatically different historical circumstances. The author of the introit weaved into the devotion to the Holy Sepulchre as memorial of the Resurrection the urge for the recovery of the Holy Land, which reflected the particular circumstances in which the friars found themselves in fifteenth-century Jerusalem. Both the introit and the Missa devota ad recuperandam Terram Sanctam discussed here belong to the

\footnotetext{
${ }^{83}$ Linder 2003, 11.

${ }^{84}$ Tyrer 1932, 123-125.

${ }^{85}$ Gaposchkin 2017, 46-9.

${ }^{86}$ Campopiano 2011, 333-344.

${ }^{87}$ Tyerman 2007, 66.

${ }^{88}$ Discussion of the letter in Tyerman 2007, 72.

89 "Nos enim ad hanc expeditionem militum animos instigavimus, qui armis suis Saracenorum feritatem declinare et Christianorum possint libertate pristine restituere". Wiederhold (ed.) 1901, 313.
} 
family of liturgical devotions created to lament the loss and pray for the recovery of the Holy Land. Whilst the missa presents a standard Western European format, the introit seems to have responded to the liturgical needs of the Jerusalem friars, who very likely employed it in their service at the Church of the Holy Sepulchre. This adjustment of Western devotions to the liturgy of the Holy Sepulchre and the centrality of the Resurrection characterized Latin liturgical practice in Jerusalem from crusader times. ${ }^{90}$ The friars were the continuators of liturgical traditions originating in practices going back to the time of the Latin Kingdom.

\section{Conclusions}

Although the call for crusade was issued many times in the fourteenth and the fifteenth centuries, and kings and princes kept "taking the cross", this never resulted in anything similar to the movement that followed Urban II's call at Clermont. The defence of Christian lands replaced the offensive for the relief of the Holy Land and expeditions for its deliverance tapered off throughout the fourteenth and fifteenth centuries. The two Hagiopolite liturgical texts discussed in this article paint a similar picture. In Jerusalem, the friars' militant liturgy had to be sheltered and their supplications for its liberation concealed behind the locked doors of the Church of the Holy Sepulchre, with patent displays only for the benefit of Latin pilgrims. The friars adjusted their mission of liturgical intercession to the expectation of European pilgrims and the limits of their legal status, that of a tolerated presence in an Islamic city. To this end, their liturgy memorialized the crusader liturgy of war. Between despondency, in the absence of military expeditions to recover the Holy City, and liturgical exhortation for its deliverance, the friars, or at least the one-hundred-year old Franciscan met by the Adornos in 1470, continued to pray for its return to "Christian hands".

Valentina Covaci

Faculty of Roman Catholic Theology, The University of Bucharest valentinavcovaci@gmail.com

${ }^{90}$ Salvadó 2016, 662-673. 


\section{BIBLIOGRAPHY}

\section{Manuscripts}

Jerusalem, Biblioteca Generale della Custodia di Terra Santa, MS MIN. 1 olim SF1278.

Jerusalem, Biblioteca Generale della Custodia di Terra Santa, MS MIN. 2 olim ZzV19.

Sevilla, Biblioteca Colombina, MS 5-2-46.

Primary sources

Bukeley B. (ed.) 1857: The Itineraries of William Wey, fellow of Eton College, to Jerusalem, A.D. 1458 and A.D. 1462 and to Saint James of Compostella A.D. 1456 from the Original Manuscript in the Bodleian Library, London.

Donnadieu J. (ed. and French trans.) 2008: Jacques de Vitry, Histoire orientale Historia orientalis, Turnhout.

Hassler K.D. (ed.) 1843: Fratris Felicis Fabri Evagatorium in Terrae Sanctae, Arabiae et Egypti peregrinationem, vol. 1 and vol. 3, Stuttgart.

Heers J. and de Groer, G. (eds. and French trans.) 1978: Itinéraire d'Anselme Adorno en Terre Sainte (1470-1471), Paris.

Hesbert R.-J. (ed.) 1968: Corpus antiphonalium officii, vol.3, Invitatoria et antiphonae. Editio critica, Rome.

Hesbert R.-J. (ed.) 1970: Corpus antiphonalium officii, vol. 4, Responsoria, versus, hymni et varia. Editio critica, Rome.

Hill R. (ed. and trans.) 1962: The Deeds of the Franks and the Other Pilgrims to Jerusalem, Oxford.

de Sandoli S. (ed. and Italian trans.) 1974: Corpus Inscriptionum Crucesignatorum Terrae Sanctae (1099-1291). Testo, traduzione e annotazioni, Jerusalem.

Shuffelton G. (ed.) 2008: Codex Ashmole 61. A Compilation of Popular Middle English Verse, Kalamazoo.

Wiederhold W. (ed.) 1901: Papsturkunden in Florenz, Göttingen.

Secondary works

Arce A. 1973: Miscelánea de Tierra Santa, vol. 3, Jerusalem.

Bird J., Peters E. and Powell J.M. 2013: Crusade and Christendom. Annotated Documents in Translation from Innocent III to the Fall of Acre, 1187-1219, Philadelphia.
Björn W. 2003: "The Negotium Terrae Sanctae in the Political Discourse of Latin Christendom, 1215 1311", The International History Review 25, 1-36.

Buc Ph. 2015: Holy War, Martyrdom, and Terror. Christianity, Violence, and the West, ca. 70 C.E. to the Iraq War, Philadelphia.

del Buey F. and Alvi, C. 2005: "Origines de la Custodia de Tierra Santa. Ayuda de los reinos de Aragó, Nápoles y Castilla (capítulo reabierto)", Archivo ibero-americano LXV, 7-96.

Bux N. (1990): Codici liturgici latini di Terra SantaLiturgical Latin Codices of the Holy Land, Fasano.

Campopiano M. 2011: "Tradizione e edizione din una compilazione di testi sulla Terra Santa proveniente dal convento francescano del Monte Sion (fine del XIV secolo)", RHT VI, 329-359.

Campopiano M. 2014: "Note sulla presenza francescana in Terrasanta: Le descrizioni dei Luoghi Santi tra XIV e XVI secolo e il ruolo de la Custodia di Terrasanta", in A. Musarra (ed.), Gli italiani e la Terrasanta, Firenze, 49-69.

Cassidy-Welch M. 2013: “The Stedinger Crusade: War, Remembrance, and Absence in ThirteenthCentury Germany", Viator 44 no. 2, 159-174.

Cenci C. 1991: "Libri liturgici miniati nel Museo Francescano di Gerusalemme", Archivum Franciscanum Historicum 84, fasc. 1-2, 487-489.

Cibin S. 2016: Libri liturgici miniati della Custodia di Terra Santa (XIII-XVIII) secolo, unpublished doctoral thesis, Università degli Studi di Verona.

Cita M. 2015: "Antifonari francescani di Terrasanta (1431-1492). 2. Santo Sepolcro, Siloe, Montana Giudea, Ebron, Fiume Giordano, Joppe, Nazareth, Damasco", Storie e linguaggi 1 fasc. 2, 259-308.

Congar Y. 1961: "Aspects ecclésiologiques de la querelle entre mendiants et séculiers dans la secode moitié du XIII ${ }^{\mathrm{e}}$ siècle et le début du XIV ${ }^{\mathrm{e}}$ ", Archives d'histoire doctrinale et littéraire du Moyen Âge 36, 35-151.

Constable G. 2001: "The Historiography of the Crusades", in A.E. Laiou and R. Parviz Mottahedeh The Crusades from the Perspective of Byzantium and the Muslim World, Washington, 1-22.

Cresi D. 1963: "Manoscritti liturgici francescani a Gerusalemme", Archivum Franciscanum Historicum $56,466-474$. 
Dalché P.G. 2010: “Cartes, réflexion stratégique et projets de croisade à la fin du XIIIe et au début du XIVe siècle. Une initiative franciscaine?", Francia 37, 87-95.

Duffy E. 2005: The Stripping of the Altars. Traditional Religion in England c. 1400-c. 1580, New HavenLondon.

Fassler M.E. 2011: Gothic Song. Victorine Sequences and Augustinian Reform in Twelfth-Century Paris, Notre Dame, Indiana.

Folda J. 1995: The Art of the Crusaders in the Holy Land 1098-1187, Cambridge.

Folda J. 2012: "Commemorating the Fall of Jerusalem. Remembering the First Crusade in Text, Liturgy, and Image", in P. Nicholas and S. Yeager (eds.), Remembering the Crusades. Myth, Image, and Identity, Baltimore, 125-145.

Gaposchkin M.C. 2013: "Louis IX and Liturgical Memory", in E. Brenner, M. Cohen and M. FranklinBrown (eds.), Memory and Commemoration in Medieval Culture, Burlington, VT, 261-276.

Gaposchkin M.C. 2014: "The Echoes of Victory: Liturgical and Para-liturgical Commemorations of the Capture of Jerusalem in the West", Journal of Medieval History 40:3, 237-259.

Gaposchkin M.C. 2016: "The Liturgical Memory of July 15, 1099. Between History, Memory, and Eschatology", in M. Cassify-Welch (ed.), Remembering the Crusades and Crusading, London- New York, 34-48.

Gaposchkin M.C. 2017: Invisible Weapons. Liturgy and the Making of Crusade Ideology, Ithaca and London.

Geltner G. 2012: The Making of Medieval Antifraternalism. Polemic, Violence, Deviance, and Remembrance, Oxford.

de Gennes J.-P. 1995: Les Chevaliers du SaintSépulcre de Jérusalem, vol. 1, Cholet.

Gumbert J.P. (1991): "Medieval Franciscan Manuscripts in Jerusalem", Liber annuus 41, 483-486.

Housley N. 2004: "Giovanni da Capistrano and the Crusade of 1456", in N. Housley (ed.), Crusading in the Fifteenth Century. Message and Impact, Basingstoke, 94-115.

Hughes A. 1982: Medieval Manuscripts for Mass and Office. A Guide to Their Organization and Terminology, Toronto-Buffalo- London.

John S. 2015: "The 'Feast of the Liberation of Jerusalem': Remembering and Reconstructing the First Crusade in the Holy City, 1099-1187', Journal of Medieval History 41:4, 409-431.

Kohler Ch. 1911: "Description de la Terre Sainte par un franciscain anonyme 1463", Revue de l'Orient Latin 12, 1-67.
Lapina E. 2012: "The Maccabees and the Battle of Antioch", in G. Signori (ed.), Dying for the Faith, Killing for the Faith, Leiden, 147-160.

Linder A. 1990: "The Liturgy of the Liberation of Jerusalem", Mediaeval Studies 52, 110-31.

Linder A. 2003: Raising Arms. Liturgy in the Struggle to Liberate Jerusalem in the Late Middle Ages, Turnhout.

Maier Ch.T. 1994: Preaching the Crusades: Mendicant Friars and the Cross in the Thirteenth Century, Cambridge.

Maier Ch.T. 2009: "Crisis, Liturgy and the Crusade in the Twelfth and Thirteenth Centuries", JEH 48 (4), 628-657.

Manion L. 2014: Narrating the Crusades. Loss and Recovery in Medieval and Early Modern English Literature, Cambridge.

Morris C. 2005: The Sepulchre of Christ and the Medieval West. From the Beginning to 1600, Oxford.

Morton N. 2010: "The Defence of the Holy Land and the Memory of the Maccabees", Journal of Medieval History 36, 275-93.

Niccolai E. 2015: “Antifonari francescani di Terrasanta (1431-1492). 1. Betlemme, Monte Sion, Betania, Monte Oliveto, 'Peregrinationes infra Ierusalem civitatem', Valle di Giosafat”, Storie e linguaggi 1 fasc. 2, 205-258;

Paviot J. 1996: "La devotion vis-à-vis de la Terre Sainte au XVe siècle: L'example de Philippe le Bon, duc de Bourgogne (1396-1467)", in M. Balard (ed.), Autour de la première croisade. Actes du Colloque de la Society for the Study of the Crusades and the Latin East (Clermont-Ferrand, 22-25 juin 1995), ed. Michel Balard, Paris, 401-411.

Sáez Guillén J.F. 2002: Catálogo de manuscritos de la Biblioteca Colombina de Sevilla, vol. 1, Sevilla.

Signori G., Introduction, in G. Signori (ed.), Dying for the Faith, Killing for the Faith. Old-Testament FaithWarriors (1 and 2 Maccabees) in Historical Perspective, Leiden, 11-36.

Saletti B. 2016: I francescani in Terrasanta (12911517), Padova.

Salvadó S. 2016: "The Medieval Latin Liturgy of the Patriarchate of Jerusalem and the Ordinal of the Holy Sepulchre (Barb. Lat. 659)", Miscellanea Bibliothecae Apostolicae Vaticanae XXII, 651-686.

Salvadó S. 2017: "Rewriting the Latin Liturgy of the Holy Sepulchre: Text, Ritual and Devotion for 1149", Journal of Medieval History 43 (4), 403-420.

Shagrir I. 2010: "The Visitatio Sepulchri in the Latin Church of the Holy Sepulchre in Jerusalem", AlMasaq: Journal of the Medieval Mediterranean 21 (1), 57-77. 
Tolan J.V. 2002: Saracens. Islam in the Medieval European Imagination, New York.

Trovato P. 2015: "Per lo studio dei più antichi processionali di Terrasanta (secoli XIV-XV)", Storie e linguaggi 1 fasc. 2, 187-204.

Tyerman Ch. 1985: "Philip VI and the Recovery of the Holy Land", EHR 100, 25-52.

Tyerman Ch. 2007: God's War. A New History of the Crusades, London.

Tyrer J.W. 1932: Historical Survey of Holy Week: Its Services and Ceremonial, London.

\section{Websites}

http://cantus.uwaterloo.ca/search?t=portio+mea+domin e+sit [accessed: December 2018]. 